\title{
Carmen Burgio
}

\section{Wisselende Portretten van Augustinus van Hippo}

Alle filosofische werken vertellen een verhaal. ${ }^{1}$ Niet alleen de werken van literaire filosofen zoals Nietzsche, maar ook van de uiterst academische filosofen zoals Kant. Net als bij een verhaal gaat het bij een filosofisch werk om een plot, de uitwerking van een conflict en de worstelingen van de protagonist om dat conflict op te lossen. In het geval van een filosofisch werk is het de filosoof die een filosofisch probleem opwerpt en probeert het probleem op te lossen door te filosoferen. Bovendien geloof ik dat in elk filosofisch werk het karakter of de persoonlijkheid van de auteur zich in meer of mindere mate bekendmaakt. In dit artikel zal het verhaal worden verteld van Augustinus van Hippo's (354-430) ideeën over de vrije wil, hoe deze door historici en filosofen zijn geïnterpreteerd en wat voor gevolgen dat heeft gehad voor het persoonlijk portret dat in de literatuur op basis van zijn denken van hem werd geschetst.

Augustinus was een laatantiek neoplatoonse filosoof, christelijk theoloog en bisschop van Hippo. Hij kan omschreven worden als een filosoof in de originele etymologische betekenis van het woord: wijsgeer of liefhebber van wijsheid. ${ }^{2}$ Augustinus zelf vertelde ons in zijn meest beroemde werk, de Confessiones (Belijdenissen), dat het Cicero's Hortensius (Over de filosofie) was dat hem inspireerde om de leerstellingen van de filosofie te bestuderen en het begin was van zijn zoektocht naar wijsheid. In dit tegenwoordig verloren werk - slechts fragmenten zijn bewaard gebleven in werken van andere laatantieke schrijvers - betoogde Cicero dat de mens het echte geluk kan vinden door filosofie te omarmen, omdat alle mensen een aangeboren verlangen hebben om te weten. ${ }^{3}$ Augustinus zelf zei daarover: 


\section{Burgio}

Quite definitely it changed the direction of my mind, altered my prayers to You, O Lord, and gave me a new purpose and ambition. Suddenly all the vanity I had hoped for I saw as worthless, and with an incredible intensity of desire I longed after immortal wisdom. ${ }^{4}$

\section{Augustinus over de vrije wil}

Augustinus pakte al vroeg in zijn carrière het probleem van de vrije wilskeuze en de oorsprong van het kwaad op. In 387/8 schreef hij het eerste boek van De libero arbitrio (Over de vrije wilskeuze) en voltooide het tweede en het derde boek in $395 .{ }^{5}$ Het probleem van de vrije wilskeuze speelde een grote rol in het kerkelijk leven van de vijfde eeuw, maar ook in het persoonlijk leven van Augustinus. Hij kwam in zijn leven herhaaldelijk terug op het compatibiliteitsprobleem van God met de vrije wilskeuze van de mens. Dit geeft aan dat de zoektocht naar het antwoord niet slechts een abstract filosofisch/theologisch onderzoek was, maar dat het vinden van het antwoord voor hem ook persoonlijk van groot belang was.

In eerste instantie was Augustinus geïnteresseerd in klassieke concepten van de menselijke vrijheid en de deugd. ${ }^{6}$ De antieke filosofen Socrates, Plato en Aristoteles beschouwden immoreel gedrag als een consequentie van een gebrek aan inzicht. Het idee dat de mens een wil moest hebben om de goede keuze te maken was bij deze filosofen nog niet vormgegeven. Augustinus creëerde een essentieel nieuw concept van de wil, dat vreemd was binnen de klassieke filosofie. ${ }^{7}$ Hij herzag de klassieke visie op de mens en zijn handelen onder invloed van het christendom en verlegde de aandacht naar de aard en noodzakelijkheid van de goddelijke genade in zijn De libero arbitrio. In dit werk stelde Augustinus dat het immorele gedrag van mensen niet een kwestie is van onwetendheid, maar dat mensen ook de wil nodig hebben om moreel te handelen. Immoreel gedrag is daarom niet alleen een gebrek aan inzicht, maar is ook een kwestie van het ontbreken van de wil om het goede te doen, zo redeneerde Augustinus in het eerste boek van zijn De libero arbitrio. ${ }^{8}$

Echter, in het tweede en derde boek lijkt Augustinus een hele andere mening te hebben. Hij beargumenteerde in deze laatste twee boeken dat de mens toch niet geheel vrij is in al zijn of haar keuzes. De vraag is immers hoe het kan dat men de ene keer het kwade wil en de andere keer het goede. Het immoreel handelen was volgens Augustinus een uiting van de aangeboren 
zondigheid van de mens, die uiteindelijk is terug te leiden op de erfzonde. De enige manier om van die zondigheid verlost te worden, en dus moreel te handelen, was door zich te richten op God. Alleen de genade van God kon de goede wil in mensen verwerkelijken volgens Augustinus. ${ }^{9}$ De strijd tussen zonde en genade werd volgens hem gekenmerkt door een intern conflict tussen een verlangen naar een hereniging met God en de aardse gewoontes van de mens. De mens kon aan dit conflict ontsnappen, niet door kennis, maar uitsluitend door een liefde voor God..$^{10}$

De aanvulling op zijn ideeën over de genade van God gaf Augustinus weer in zijn Retractiones, geschreven aan het einde van zijn leven (rond de jaren 426/427). ${ }^{11}$ In dit werk herlas hij 93 eerdere werken van hemzelf, waarin hij kritiek leverde en zijn werk aanpast waar nodig. In de Retractiones leek hij tot de definitieve conclusie te komen dat de genade van God in een dergelijke mate essentieel is voor het herstel van het oorspronkelijke goed voor de zondeval en voor het bereiken van het hogere goed, dat de vrije wilskeuze eronder leek te zwichten. Augustinus kwam in zijn laatste werk dus terug op zijn eerdere standpunten over de vrije wilskeuze. Het standpunt, dat hij in het eerste boek van De libero arbitrio bekritiseerde, leek Augustinus in de Retractiones juist te verdedigen.

Om deze reden is De libero arbitrio vaak aangedragen om een omslag in Augustinus' ideeën aan te tonen: van een platonisch geïnspireerd optimisme over de menselijke vermogens, zoals geïllustreerd in boek één, naar de pessimistische visie in het tweede en derde boek, voornamelijk geïnspireerd door de geschriften van de apostel Paulus, die sprak over het onvermogen en de moeite die het mensen vanwege de erfzonde kostte om het goede te doen. ${ }^{12}$ Recentelijk zijn er meerdere studies gepubliceerd die vraagtekens zetten bij de veronderstelde discontinuïteit van Augustinus' denken. ${ }^{13}$ Augustinus' De libero arbitrio heeft een belangrijke rol in dit debat vanwege het belang dat het heeft gehad voor het vormgeven van de christelijke doctrine in de late oudheid. De herlezing van Augustinus' werk bracht een herinterpretatie van zijn ideeën over de vrije wil en een nieuw portret van zijn karakter.

\section{Een vroege en een late Augustinus}

Peter Browns intellectuele biografie Augustine of Hippo: A Biography, oorspronkelijk geschreven in 1967, had een grote invloed op de verspreiding van het idee over de inconsistentie van Augustinus' denken. Brown verteld in dit werk het verhaal van Augustinus' leven, waar hij hem omschrijft 


\section{Burgio}

als een 'rusteloze geest', en zijn leven schetst tegen de achtergrond van de ondergaande Romeinse wereld en de opkomst van nieuwe machten, die een voorteken waren van de middeleeuwse wereld die weldra haar intrede zou doen. ${ }^{14}$ In de decennia na de eerste druk vestigde het boek zich als het standaard werk over Augustinus' leven en zijn leer. Brown constateerde een verandering in Augustinus' denken en maakte een onderscheid tussen een 'vroege' en een 'late' Augustinus. De vroege Augustinus geloofde, volgens Brown, dat mensen perfectie en verlossing konden bereiken in dit leven. Met andere woorden, het was mogelijk voor mensen om de moraliteit te herstellen die verloren ging door de erfzonde, door zich toe te leggen op de filosofie.

In zijn Biography maakt Brown een onderscheid tussen twee werelden; een 'oude' en een 'nieuwe' wereld. Het eerste boek van De libero arbitrio behoort volgens hem tot de oude wereld. Tot deze klassieke wereld behoort de 'vroege' optimistische Augustinus die geloofde dat mensen in dit leven en in deze wereld geluk kunnen bereiken. Augustinus kwam volgens Brown na zijn paulinische revolutie in de jaren 390 tot het inzicht dat niet al het moreel handelen in de macht van de mens ligt, maar voor een deel ook buiten zijn bereik: 'It is the most drastic change that a man may have to accept: it involved nothing less than the surrender of the bright future he thought he had gained at Cassiciacum. ${ }^{15}$

In hoofdstuk vijftien van zijn biografie, genaamd The Lost Future, beschrijft Brown Augustinus' verandering van zijn denken midden jaren 390 van een optimistisch christelijk neoplatonisme naar een pessimistisch christendom. In dit hoofdstuk beeldt Brown Augustinus af als een man die de middelbare leeftijd nadert en in het reine komt met de beperkingen van de mensheid, maar ook met zijn eigen beperkingen:

A new tone has come to suffuse Augustine's life. He is a man who has realized that he was doomed to remain incomplete in his present existence, that what he wished for most ardently would never be more than a hope, postponed to a final resolution of all tensions, far beyond this life. ${ }^{16}$

Augustinus ontwikkelde zijn pessimistische ideeën over de vrije wil verder in de polemiek met het Pelagianisme, een heterodox-christelijke theologische positie die stelde dat de erfzonde de menselijke natuur niet heeft aangetast en dat mensen de vrije wil hebben om menselijke perfectie te bereiken zonder goddelijke genade. Zijn antwoord op het Pelagianisme formuleerde Augustinus in de Retractiones. In dit werk bespreekt hij zijn eerdere ideeën over de vrije wil zoals geformuleerd in De libero arbitrio. De libero arbitrio 
in het bijzonder verdiende het om door het scherpe redeneringsvermogen van Augustinus te worden herzien, omdat de Pelagiaanse tegenstanders beargumenteerd hadden dat Augustinus' denkbeelden over de menselijke vrijheid weerklonken in hun eigen ideeën. Augustinus verdedigde zich tegen de Pelagianen door zijn standpunt over de compatibiliteit van de goddelijke genade en de vrije wilskeuze te verduidelijken. Hij probeerde geen waarderend onderscheid te maken tussen beide en het belang dat aan de genade of de vrije wil toegeschreven moet worden wordt door Augustinus volledig gelijkgesteld.

Het redactiewerk van Augustinus in de Retractiones had het doel om zijn eigen fouten te verbeteren, zijn lezers te behoeden voor onjuiste (christelijke) opvattingen en ook om zijn lezers aan te sporen om eenzelfde ontwikkeling te ondergaan als hemzelf: 'One who reads my works in the order in which they were written will find out how I progressed while writing. ${ }^{17}$ Augustinus' verschuiving van anti-Manicheïsche naar anti-Pelagische polemiek verklaart Augustines meer pessimistische perspectief op de gevolgen van de zondeval en zijn leer van goddelijke genade en predestinatie die de keuze voor vrije wil aanzienlijk ondermijnde. De Retractiones liet ons zien hoe Augustinus' De libero arbitrio verkeerd kon worden geïnterpreteerd door zijn tijdgenoten, maar is dit voldoende reden om een radicale breuk tussen de ideeën van de vroege en de late Augustinus te betogen? Augustinus zelf concludeerde in de Retractiones: '(...)observe how long before the Pelagian heresy had come into existence we spoke as though we were already speaking against them. ${ }^{\text {,18 }}$ Augustinus' eigen verklaring over zijn ontwikkeling kan niet zomaar van de hand worden gedaan en deze breuk in zijn denken is dan ook in latere studies bestreden, niet in de minste plaats door Brown zelf.

\section{Nieuw bewijs}

Peter Brown kwam terug op zijn eerdere typering van Augustinus in een nieuwe editie van zijn biografie van de bisschop in 2000. De ontdekking van nieuw bewijsmateriaal over de latere jaren van Augustinus' leven was de reden voor Brown om zijn eerdere visie op de oude bisschop te herzien. Deze ontdekking was de reden waarom er na 2000 een nieuwe generatie wetenschappers opkwam die de geschriften van Augustinus opnieuw beoordelen. Toen Brown zijn biografie schreef in de jaren 1960 was het moeilijk voor te stellen dat de ontdekking van verloren werken van Augustinus zouden leidden tot een herwaardering van Augustinus' 


\section{Burgio}

gedachtegoed en karakter. In 1975 ontdekte Johan Divjak 27 tot dan toe onbekende brieven van Augustinus en vijftien jaar later ontdekte François Dolbeau 26 onbekende preken. In een nieuwe uitgave van zijn biografie concludeerde Brown op basis van het nieuwe bewijs: 'I have found the Augustine of the Dolbeau sermons and of the Divjak letters to be considerably less the authoritarian, stern figure that my reading of the evidence available to me in the 1960's had led me to suspect. ${ }^{19}$

De preken brachten ons terug naar het Romeinse Noord-Afrika, een plek waar de Romeinse religies nog welig tierden en het christendom nog niet de dominante religie was. In de preken ontmoeten we een Augustinus die de dialoog aangaat met de niet christelijke religies van het Romeinse rijk. ${ }^{20} \mathrm{Zijn}$ stem in de preken is niet een relaas van een gefrustreerde eenzame oude man die ruzie zoekt met zijn theologische tegenstanders, maar de stem van een bisschop die het zielenheil van de mensen altijd vooropstelde. Augustinus geloofde dat het christendom deze verlossing van de ziel naar de mensen kon brengen. Het christendom was voor iedereen en iedereen kon de goddelijke genade ontvangen. ${ }^{21}$ Sterker nog, niemand kon zonder de goddelijke genade volgens Augustinus. De preken geven een totaal ander beeld van Augustinus' ideeën over de genade, predestinatie en de vrije wil. Augustinus sprak in zijn preken niet over de hulpeloosheid van de menselijke ziel, wat voor lange tijd werd geïdentificeerd met de boodschap van het vroege Christendom. Hij sprak daarentegen over hoop voor het bereiken van verlossing door middel van de goddelijke genade.

De Divjak-brieven laten ons een Augustinus zien in dialoog met zijn tijdgenoten, op zoek naar de waarheid waar hij naar verlangde. Deze brieven waren de aanleiding voor Browns herziene visie van Augustinus latere geschriften gericht tegen de Pelagianen. John Burnaby - volgens Brown 'the finest expositor of Augustine's thought available to me at the time' beoordeelde Augustinus' laatste werken over de genade en predestinatie als geschreven door een man 'whose energy has burnt itself out, whose love has grown cold. ${ }^{22}$ Brown geeft toe dat hij onder de indruk was van de autoriteit van Burnaby, dat hij zich heeft laten beïnvloeden door Burnaby's observaties in de jaren 1960 en dat hij te hard over Augustinus heeft geoordeeld. ${ }^{23}$ Toch is Burnaby's oordeel volgens Brown wel begrijpelijk. Het representeerde een poging van een moderne Christen om de zware last die Augustinus' gedachtegoed - en vooral zijn predestinatieleer - op de schouders van alle volgende generaties legde, enigszins te verlichten. ${ }^{24}$ De autoritaire figuur geschetst door een jonge Brown maakt plaats voor een bisschop die uitreikt 
naar de verste uithoeken van de wereld en zijn volledige aandacht besteedt aan elk probleem dat de gelovigen zou kunnen bezighouden. ${ }^{25}$ Gebombardeerd met vragen door zijn tijdgenoten lijkt Augustinus minder stug en meer betrokken bij de gelovigen en bij het theologische debat: 'Augustine's work as a controversialist would have been regarded by contemporaries as reflecting a warm and solid virtue, highly esteemed by the ancient Romans. ${ }^{26}$

\section{Eén Augustinus}

In de historiografie werd vaak naar de Retractiones verwezen om aan te tonen dat Augustinus' gedachtegoed inconsistent is. De correcties die hij aanbrengt zouden erop duiden dat hij zijn eerdere standpunten herzag. Door de Retractiones in te delen op chronologische volgorde lijkt Augustinus deze 'vroege en late Augustinus' dichotomie zelf ook aan te moedigen. ${ }^{27}$ Tegenwoordig zijn de meeste historici het erover eens dat het doel van de Retractiones niet was om zijn eerdere werk te herroepen, maar om zijn gedachtegoed opnieuw te overdenken. Augustinus probeerde vat te krijgen op de passages in zijn werk waarvan hij dacht dat het verdere uitleg behoefte, een verdediging of verwerping. ${ }^{28}$ Dit gecombineerde proces van redactie en introspectie maakt dat de Retractiones treffend omschreven kan worden als Augustinus' gewetensonderzoek. ${ }^{29}$

Deze inzichten leidden tot sterke kritiek vanuit de rest van de academische wereld op Browns originele biografie over Augustinus. Eën van deze critici was Carol Harrison, die haar kritiek uitte in een publicatie uit 2006 getiteld Rethinking Augustine's Early Theology: An argument for Continuity. Zij beschouwt Peter Browns biografie als de voornaamste oorzaak van het voorheen algemeen geaccepteerde idee van discontinuïteit van Augustinus' gedachtegoed. Harrison beschrijft in haar voorwoord de trend onder historici om de net tot het christendom bekeerde Augustinus te beschouwen als een totaal ander persoon dan de bisschop van Hippo. ${ }^{30}$ In haar boek gaat ze tegen deze trend in en probeert ze te demonstreren dat er een 'clear continuity [is] between Augustine the new convert and Augustine the new bishop' en dat Browns karikatuur van de vroege Augustinus 'resulted in a gross distortion of his subsequent development. ${ }^{31}$

Harrisons doel is om deze twee versies van Augustinus samen te brengen in één persoon. Als zodanig gaat ze op zoek naar verwijzingen die betrekking hebben op de zonde en genade in Augustinus' De libero arbitrio. Ze beargumenteert dat zijn idee van de wil al in zijn hoofd speelde toen hij 


\section{Burgio}

begon te schrijven aan De libero arbitrio in 388: 'He never held the free choice of the will as the origin of evil without also being acutely aware of its fallen ignorance and difficulty and its need for God's grace.. ${ }^{32}$ Met andere woorden, om de argumenten van de Pelagianen te weerleggen, was het niet nodig voor Augustinus om in zijn Retractiones zijn eerdere standpunten over de vrije wilskeuze radicaal te herzien. Het was genoeg om zijn ideeën over de goddelijke genade te verduidelijken. ${ }^{33}$

Carol Harrisons benadering ten opzichte van de ontwikkeling van Augustinus denken legt de nadruk op een van tevoren uitgewerkte argumentatieve helderheid en precisie. Ik deel Carol Harrisons conclusie dat Augustinus tijdens zijn vervaardiging van De libero arbitrio altijd een totaal werk in gedachten heeft gehad en dat Augustinus' De libero arbitrio en Retractiones gelezen moeten worden als één coherent argument. Toch liggen de zaken mijns inziens genuanceerder en tegelijk ook ingewikkelder dan Carol Harrison doet voorkomen. In haar voorwoord geeft Harrison toe dat 'at times, [I] have overstated it and failed to allow for the new convert to evolve into the new bishop. ${ }^{34}$ In haar argument voor continuiteit van Augustinus' ideeën impliceert ze statische eenvormigheid van al Augustinus' ideeën en sluit daarmee een ontwikkeling van zijn ideeën uit.

Ideeën zijn niet statisch maar manifesteren zich in verschillende contexten en tijdsperiodes. ${ }^{35}$ Met andere woorden, een belangrijk punt van kritiek op Carol Harrison is dat Augustinus als persoon niet onveranderlijk was en zijn ideeën evenmin. Dit betekent dat historici Augustinus moeten plaatsen in de sociale, politieke en culturele structuren van de late oudheid. Peter Brown was met zijn intellectuele biografie één van de eersten die Augustinus en zijn ideeën plaatste in hun historische context van de laatantieke wereld. Daarom moeten we wellicht concluderen dat Browns onderscheid tussen een 'vroege' en een 'late' Augustinus geen groot onrecht deed aan de oude bisschop. Echter, Harrison liet zien dat deze twee versies van Augustinus meer op elkaar leken dan Brown had kunnen bedenken in 1967. ${ }^{36}$

\section{Een nieuwe Augustinus}

James Wetzels boek Augustine and the limits of virtue is een goed voorbeeld van een historische benadering van laatantieke theologische en filosofische teksten. Wetzel beargumenteerde dat in dat er in de historiografie een te negatief beeld wordt geschetst over Augustinus en zijn ideeën, omdat er betoogd werd dat de plaats die Augustinus aan de godsgenade toewees zo 
groot was dat er nauwelijks ruimte overbleef voor de vrije wil. ${ }^{37}$ In zijn boek bood hij een nieuwe interpretatie op Augustinus' teksten en theorie over de vrije wil door een gedetailleerde analyse te geven van zijn teksten. Hoewel Wetzel ons een nauwkeurige reconstructie gaf van Augustinus' filosofische argumenten over de vrije wil, is het doel van zijn boek niet om ditzelfde intellectuele probleem te verdedigen of te weerleggen. Integendeel, zijn doel was om Augustinus' ideeën over de vrije wil te begrijpen in plaats van te evalueren.

Wetzel is zich bewust van de notie dat ideeën historisch bepaald zijn. Hij beweert dat de pessimistische interpretatie van Augustinus en zijn ideeën een gevolg was van verkeerde vooronderstellingen en door het verbinden van waardeoordelen aan ideeën. Augustinus' inzichten over de vrije wil werden dan ook niet op waarde geschat als gevolg van een anachronistisch onderscheid tussen theologie en filosofie. De auteur liet zien dat, hoewel Augustinus zijn geschillen met filosofie onderkende, hij nooit zijn fascinatie verloor voor de Stoïcijnse concepten van geluk en deugd en de mogelijkheid dat een mens dit kan bereiken. Volgens Wetzel is Augustinus' afscheid van de filosofie te vaak geïnterpreteerd als 'an exercise in pessimism and cynicism. ${ }^{38}$ Deze interpretaties 'overlook the continuity between his early philosophical preoccupation with virtue and human freedom and his later theological preoccupation with grace. ${ }^{39}$ Augustinus verwierp de klassieke filosofie vanwege haar onrealistische waardering van de menselijke conditie. Echter, hij liet- nooit het ideaal van de laatantieke filosofie los: het vinden van geluk en verlossing. Wat veranderde in Augustinus' filosofie was volgens Wetzel 'not the nature of the ideal but the manner of its appropriation. ${ }^{40}$

Dit aspect van Augustinus' denken is vaak verkeerd begrepen, doordat filosofen zijn idee van de vrije wil testen op overtuigingskracht door een vergelijking met moderne ideeën over de vrije wil - voortgebracht in een wereld waar religie niet meer vanzelfsprekend is. ${ }^{41}$ In de historiografie is Augustinus een dogmatisch rigorisme in de schoenen geschoven, omdat Augustinus zoveel mogelijk aan God zou hebben toegeschreven en zo weinig mogelijk aan de mens, wat de mens zou reduceren tot levende marionetten. ${ }^{42}$ Wetzel noemt Gerard O'Daly in zijn boek ter illustratie voor het algemeen aanvaarde standpunt in de wetenschap dat Augustinus de vrije wil identificeerde met vrijheid van spontaniteit of vrijheid van beperkingen. ${ }^{43}$ Veel filosofen geloven tegenwoordig dat een gepredestineerd leven niet tegelijkertijd vrij kan zijn. ${ }^{44}$ Augustinus was het niet eens met dit idee: 'He characterizes free will as our being moved to act wholly in accordance with 


\section{Burgio}

the good.' Wetzel legt uit dat 'When we represent the good intelligibly, we are moved by God. Hence freedom coextends with grace. ${ }^{45}$ Met andere woorden, Augustinus zag uiting geven aan het goede als een vorm van vrijheid die niet herleidbaar is tot moderne ideeën over vrijheid zoals de vrijheid om het kwade te willen of het hebben van alternatieve mogelijkheden. ${ }^{46}$

Historici en filosofen die Augustinus' ideeën vergelijken met moderne ideeën over de vrije wil benaderen denkers uit het verleden en hun teksten alsof het hun eigentijdse collega's waren. Deze collegiale benadering riskeert het geven van een reconstructie van een tekst die niet zijn status als historisch document erkent. ${ }^{47}$ Deze benadering negeert het feit dat denkers uit het verleden niet onze collega's kunnen zijn, vanwege verschillen in taal, mentaliteit en chronologie. ${ }^{48}$ Hoewel Wetzel ook deze valkuilen van de collegiale benadering benadrukte, erkende hij ook dat we Augustinus niet kunnen interpreteren door ook op een bepaalde manier met hem het filosofische gesprek aan te gaan. ${ }^{49}$ Anders gezegd: Augustinus kan niet begrepen worden zonder in beschouwing te nemen wat hij probeerde te zeggen, wat hij misschien gezegd zou hebben en wellicht zelfs wat hij gezegd zou moeten hebben. ${ }^{50}$ Het bestuderen van filosofische teksten uit het verleden kan kortom niet zonder interpretatie. En deze interpretatie is altijd een intellectuele exercitie. Het onderscheid tussen interpretatie en reconstructie is niet altijd duidelijk wanneer we ons bezighouden met teksten uit het verleden. Concluderend kunnen we stellen dat filosofie en niet intellectuele geschiedenis niet noodzakelijk twee totaal verschillende bezigheden zijn.

Het soteriologisch karakter van Augustinus' denken is bepalend voor de manier waarop zijn ideeën over de vrije wilskeuze begrepen moeten worden. Het begrijpen van de werkelijkehied en het praktiseren van zijn geloof hadden volgens Augustinus invloed op de lotsbestemming van de mens. Wetzel zag in dat als we Augustinus proberen te begrijpen we ons bewust moeten zijn van dit doel om filosofische en religieuze zaken met elkaar te verenigen. Sinds Immanuel Kant houdt de filosofie zich voornamelijk bezig met de epistemologie van de natuur en de structuren van de werkelijkheid door middel van louter rationele argumenten. Westerse filosofie is tegenwoordig een academische discipline en wordt beschouwd als een professionele intellectuele bezigheid die aan het einde van de werkdag terzijde kan worden gelegd. ${ }^{51}$ Filosofie is daarmee losgeraakt van de persoonlijke zoektocht die voor Augustinus zo belangrijk was. Augustinus' filosofische inspanningen kunnen niet gescheiden worden van zijn persoonlijke zoektocht naar het bereiken van verlossing. Hij zette zowel het geloof als de rede in tijdens zijn 
zoektocht naar de aard van de werkelijkheid en was ervan overtuigd dat het geloof tot een beter en completer begrip daarvan kon leiden. ${ }^{52}$

Ten slotte wil ik graag nog de historische context toelichten waarin Augustinus leefde, schreef en filosofeerde. Het antwoord van Augustinus op het probleem van de vrije wil ontstond naar aanleiding van concrete vragen die voortkwamen uit de historische context waarin hij leefde. Deze historische context van Augustinus werk was het ondergaan en de transformatie van de Romeinse traditie. De politieke en maatschappelijke situatie vroeg om een antwoord vanuit gestelde vragen in christelijk perspectief, hetgeen Augustinus probeerde te formuleren in zijn geschriften. De grootste oorzaak voor de heropening van De libero arbitrio in de Retractiones was de val van Rome in 410. Augustinus resideerde destijds in Hippo, maar bij hem kwam de schok van de val van de eeuwige stand binnen onder andere door de stroom vluchtelingen die uitweek naar Noord-Afrika. Augustinus vergeleek Rome met Jeruzalem: net zoals de mensen van Israël in ballingschap in Babylon leefden, zo leefden Gods mensen ontheemd uit hun thuisland in de hemel als migranten en vluchtelingen op aarde, zij waren vreemdelingen geworden in het Romeinse Rijk. Rome was vol met deze ontheemde christenen en de heiligdommen van de martelaren, de belangrijkste doden die stierven voor hun geloof. ${ }^{53}$ Zowel niet-christenen als christenen wilden weten waarom de God van de christenen de stad niet had beschermd. Voor Augustinus was de invasie van Rome geen ramp waarna de wereld nooit meer hetzelfde zal zijn. Hij plaatste de gebeurtenis in een tijdsperspectief. Rome was niet van de aardbodem geveegd zoals de andere Bijbelse steden Sodom en Gommorra: veel mensen overleefden, of ontsnapten aan het geweld en zouden terugkeren, of zij zochten hun heil in andere plaatsen. De val moest volgens Augustinus begrepen worden als remedie voor de menselijke zonde. ${ }^{54}$ Augustinus wilde op deze manier de mensen hoop geven, maar ook het geloof verdedigen en sommige zaken herzien.

\section{Besluit}

Een portret suggereert een statisch beeld. Dit artikel heeft echter laten zien dat onder invloed van verscheidene interpretaties van zijn denken, Augustinus' portret op veel verschillende manieren is geschetst en ingekleurd. Denkers zijn niet statisch, omdat zij de dialoog aangaan met anderen, zich ontwikkelen en oud worden - en hun ideeën veranderen met hen mee. Wetzels interpretatie van Augustinus' theorie van de vrije wil 


\section{Burgio}

ageert tegen Harrisons platonische begrip van ideeën. In haar poging om Augustinus vroege en late gedachtegoed bij elkaar te brengen deed ze het bijna lijken alsof de ideeën van Augustinus al in een oervorm bestonden in een platonische ideeënwereld. Wetzel benadrukte daarentegen de evolutie van Augustinus' ideeën en de manier waarop veranderende polemische contexten bepaalde ontwikkelingen in zijn denken teweegbrachten. Dit brengt het werk van Wetzel dichter bij Browns benadering van zijn intellectuele biografie, aangezien hij Augustinus' denken begrijpt in de onmiddellijke context van zijn eigen leven. Augustinus leefde zijn leven niet in eenzaamheid, hij leefde en dacht te midden van andere filosofen en theologen en ging met hen in dialoog. Uiteraard geldt dit voor alle denkers uit het verleden en ook voor de denkers in het hier en nu. Wetzel erkende dat Augustinus als persoon niet onveranderlijk is en zijn ideeën evenmin. We moeten het daarom eens zijn met Wetzels opmerking: 'It would probably do little harm to our understanding of Augustine's theology to allow him the luxury of an occasional inconsistency. ${ }^{55}$ We moeten Augustinus' denken dan ook niet onderwerpen aan strengere normen dan we in andere gevallen zouden doen. Ook van onze eigen theorieën kunnen we onderkennen dat deze provisorisch en feilbaar zijn en we kunnen accepteren dat ze wellicht op een later moment herzien moeten worden, maar dat ze desondanks op dit moment voldoende leidraad bieden voor onze eigen persoonlijke oriëntatie in de wereld.

Het zijn niet alleen de intellectuele netwerken van een denker en de historische context waarin hij leefde die belangrijk zijn voor het begrijpen van filosofische werken uit het verleden, maar ook de dialoog die wij zelf aangaan met deze teksten vanuit onze eigen mentale wereld is daarbij van belang. De intellectuele geschiedenis kan op deze manier inzicht bieden in de mentale wereld van denkers uit het verleden, maar kan ons ook nieuwe inzichten geven in onze eigen mentale wereld. Het kan de structuren ontrafelen van de erfenis van de denkers uit het verleden, maar het kan ons ook laten zien wat we zijn verloren: manieren van praten en denken. ${ }^{56} \mathrm{Dit}$ is de filosofische dimensie van intellectuele geschiedenis, het proberen begrijpen van filosofische teksten uit het verleden vanuit onze eigen ideeënwereld. De intellectuele geschiedenis heeft deze persoonlijke interpretatie nodig. Dit is niet zonder historisch besef, maar geeft ons juist groter inzicht van wat wij zelf in onze studies inbrengen: onze interpretaties, hypothesen en theorieën. 


\section{Noten}

1. Quote van Umberto Eco uit een interview, gevonden in:

Umberto Eco, Adelaida Lopez, Marithelma Costa and Donald Tucker, Diacritics 17, nr. 1 (lente, 1987): 48.

2. Augustinus zag zichzelf niet als filosoof. Hij was opgeleid tot retor en van beroep was hij eerst retor en docent in de retorica en later bisschop van Hippo. Zie Paul Vincent Spade, "Medieval Philosophy," Stanford Ecyclopedia of Philosophy, 3 augustus 2004, laatst gewijzigd 15 maart 2016, geraadpleegd 15 februari 2020, https://plato.stanford. edu/entries/medieval-philosophy/\#Augustine.

3. Vincent Hunink, "Hating Homer, Fighting Virgil: Books in Augustine's Confessions," Ancient Narrative; Ans 12 Readers and Writers in the Ancient Novel (2009): 263.

4. Uit een Engelse vertaling van de Confessiones: Augustinus, Confessions, vert. F.J. Sheed, ed. Michael P. Foley (Indianapolis: Hacket Publishing Company, 2006), 89.

5. Simon Harrison, Augustine's Way into the Will: The Theological and Philosophical Significance of De Libero Arbitrio (Oxford: Oxford University Press, 2006), 19.

6. James Wetzel, Augustine and the Limits of Virtue (Cambridge: Cambridge University Press, 1992), ii.

7. James Wetzel, Augustine and the Limits of Virtue, ii.

8. Zie voor een Nederlandse vertaling: Augustinus, De Libero Arbitrio: Over de Vrije Wilskeuze, vert. Olav J. Albers (Baarn: Ambo, 1994).

9. Tjeerd van de Laar en Sander Voerman, Vrije wil: Discussies over Verantwoordelijkheid, Zelfverwerkelijking en Bewustzijn (Rotterdam: Lemniscaat, 2011), 19.

10. Wetzel, 4.

11. Zie voor een Engelse vertaling van dit werk: Augustinus, The Retractations, vert. Mary Inez Bogan (Washington, D.C.: Catholic University of America Press, 1999).

12. Voorbeelden van wetenschappers die een omslag in Augustinus denken waarnemen: Paul Séjourné, "Les Conversions de Saint Augustin d’Après le 'De Libero Arbitrio, Livre I," Revue des Sciences Religieuses 25 (1951): 243-64, 333-63; Robert J. O’Connell, “De Libero Arbitrio I: Stoicism revisited," Augustinian Studies 1 (1970): 49-68; Eugene TeSelle, Augustine the Theologian (Londen: Burns en Oates, 1970); William S. Babcock, "Augustine's Interpretation of Romans," Augustinian Studies 10 (1979): 55-74; Peter Browns originele werk uit 1967. Later herziet hij zijn visie over de bisschop. Augustine of Hippo: A Biography. New Edition with an Epilogue (Berkeley, CA: University of California Press, 2000).

13. Voorbeelden van wetenschappers die vraagtekens zetten bij de incoherentie van Augustinus' ideeën: Bret W. Smith, “Augustine's Natural Law Theory in De Libero Arbitrio," Irish Theological Quarterly 80 (2015): 111-135; Carol Harrison, Rethinking Augustine's Early Theology: an Argument for Continuity (Oxford: Oxford University Press, 2006); Simon Harrison, Augustine's Way into the Will: the Theological and Philosophical Significance of De Libero Arbitrio (Oxford: Oxford University Press, 2006); James Wetzel, Augustine and the Limits of Virtue (Cambridge: Cambridge University Press, 1992). 


\section{Burgio}

14. Peter Brown, Augustine of Hippo: A Biography. New Edition with an Epilogue (Berkeley, CA: University of California Press, 2000)115, 191, 194, 369.

15. Peter Brown, Augustine of Hippo, 140.

16. Brown, 150.

17. Augustine, The Retractations, trans. Mary Inez Bogan (Washington, D.C.: Catholic University of America Press, 1999), 5.

18. Augustinus, The Retractations 1.8.6., 38.

19. Brown, 445.

20. Idem, 458.

21. Idem, 460 .

22. John Burnaby, Amor Dei. A study of the religion of Saint Augustine (1938: Herdruk: Canterbury Press: Norwich, 1991), 231; Brown, 466.

23. Brown, 466.

24. Ibidem.

25. Ibidem.

26. Idem, 492.

27. Anita Obermeier, The History and Anatomy of Auctorial Self-Criticism in the European Middle Ages (Amsterdam: Rodopi, 1999), 54.

28. Augustinus, The Retractations, 3-4.

29. Overigens werd de Retractiones door Joseph de Ghellinck al op deze manier omschreven in de jaren 1940. Joseph de Ghellinck, Patristique et Moyen Âge: Études d'Histoire Littéraire et Doctrinale (Gembloux: Duculot, 1949), 345.

30. Carol Harrison, Rethinking Augustine's Early Theology: An Argument for Continuity (Oxford: Oxford University Press, 2006), vi.

31. Carol Harrison, Rethinking Augustine’s Early Theology, vi, 14.

32. Harrison, 237.

33. Ibidem.

34. Idem, vii.

35. Peter E. Gordon en Amabel B. James. "What is Intellectual History? A Frankly Partisan Introduction to a Frequently Misunderstood Field.” Harvard University (maart 2012): 18-19, http://projects.iq.harvard.edu/files/history/files/what_is_intell_ history_pgordon_mar2012.pdf.

36. Dit nieuwe perspectief op Augustinus' continuïteit ging samen met nieuwe ontwikkelingen in de benadering van de laatantieke perioden in de jaren 1970. Peter Brown was zelf een van de pioniers die een nieuw perspectief boden op de Late Oudheid. Brown nam afstand van Edward Gibbons paradigma van "decline and fall" in zijn boek The World of Late Antiquity gepubliceerd in 1971 en verving deze concepten met concepten als transformatie, transitie, evolutie, continuïteit, vernieuwing en accommodatie. Bovendien verschoof hij de aandacht van politieke en militaire geschiedenis naar de sociale en culturele aspecten van de periode. Dit had tot gevolg dat Late Oudheid studies een interdisciplinair karakter kreeg. Zie: Peter Brown, The World of Late Antiquity: Ad 150-750 (New York: Norton, 1989. Zie ook voor een overzicht van de historiografie van deze periode: Jan Willem Drijvers, "Van Decline and Fall naar een wereld van Late Oudheid," Groniek 44, nr. 191 (Februari, 
2012): 13.

37. Wetzel, 220.

38. Idem, 106.

39. Idem, 16.

40. Idem, 16.

41. Idem, 219, 232.

42. Olav J. Albers, inleiding voor, Augustinus, Over de vrije wilskeuze, vert. Olav J. Albers (Baarn: Ambo, 1994). 20.

43. Wetzel, 220; Gerard O'Daly, "Predestination and Freedom in Augustine's Ethics," in The Philosophy in Christianity, ed. Godfrey Vesey (Cambridge: Cambridge University Press, 1989), 85-97.

44. Wetzel, 216.

45. Idem, 216.

46. Idem, 221.

47. Michael Edwards, "Philosophy, Early Modern Intellectual History, and the History of Philosophy." Metaphilosophy 43, nr. 1-2 (2012): 86, doi:10.1111/j.14679973.2011.01731.x.

48. Michael Edwards, "Philosophy, Early Modern Intellectual History," 86.

49. Wetzel, 219.

50. Idem, xi-xii.

51. Sue Hamiliton, Indian Philosophy: A Very Short Introduction (New York: Oxford University Press, 2001), 1.

52. Wetzel, 113.

53. Augustinus, "Sermon. 105.9 The Works of Saint Augustine for the Twenty-First Century," vert. Edmund Hill, in Sermons on the New Testament, 94A-147A, ed. John E. Rotelle (Brooklyn: New City Press, 1992), 88-96.

54. Gillian Clark, "City of Books: Augustine and the World as Text," in The Early Christian Book, ed. William E. Klingshirn en Linda Safran (Washington, D.C.: Catholic University of America Press, 2007), 122.

55. Wetzel, 166.

56. Annabel Bret, "What is Intellectual History Now?" in What is History Now, ed. David Cannadine (Palgrave Macmillan: Basingstoke en New York, 2002), 128. 